\title{
Optimization on Temperature Strategy of BOF Vanadium Extraction to Enhance Vanadium Yield with Minimum Carbon Loss
}

\author{
Zhen-Yu Zhou ${ }^{1, *(1)}$ and Ping Tang ${ }^{2, *}$ \\ 1 Hunan Institution of Science and Technology, No.439, Xueyuan Road, Yueyang 414000, China \\ 2 College of Materials Science and Engineering, Chongqing University, No.174, Shazheng Street, \\ Shapingba District, Chongqing 400044, China \\ * Correspondence: zhzy@hnist.edu.cn (Z.-Y.Z.); tping@cqu.edu.cn (P.T.)
}

check for updates

Citation: Zhou, Z.-Y.; Tang, P. Optimization on Temperature Strategy of BOF Vanadium Extraction to Enhance Vanadium Yield with Minimum Carbon Loss. Metals 2021, 11, 906. https://doi.org/10.3390/ met11060906

Academic Editor: Dariush Azizi

Received: 29 April 2021

Accepted: 28 May 2021

Published: 2 June 2021

Publisher's Note: MDPI stays neutral with regard to jurisdictional claims in published maps and institutional affiliations.

Copyright: (C) 2021 by the authors. Licensee MDPI, Basel, Switzerland. This article is an open access article distributed under the terms and conditions of the Creative Commons Attribution (CC BY) license (https:/ / creativecommons.org/licenses/by/ $4.0 /)$.

\begin{abstract}
During the vanadium extraction process in basic oxygen furnace (BOF), unduly high temperature is unfavorable to achieve efficient vanadium yield with minimum carbon loss. A new temperature strategy was developed based on industrial experiments. The new strategy applies the selective oxidation temperature between carbon and vanadium $\left(T_{\mathrm{sl}}\right)$ and the equilibrium temperature of vanadium oxidation and reduction $\left(T_{\text {eq }}\right)$ for the earlier and middle-late smelting, respectively. Industrial experiments showed $56.9 \mathrm{wt} \%$ of $\mathrm{V}$ was removed together with carbon loss for $5.6 \mathrm{wt} \%$ only in the earlier smelting. Additionally, $30 \mathrm{wt} \%$ of vanadium was removed together with carbon loss by $13.4 \mathrm{wt} \%$ in middle-late smelting. Applicability analyses confirmed $T_{\text {eq }}$ as the high-limit temperature, vanadium removal remains low and carbon loss increased sharply when the molten bath temperature exceeded $T_{\text {eq. }}$. With the optimized temperature strategy, vanadium removal increased from $69.2 \mathrm{wt} \%$ to $92.3 \mathrm{wt} \%$ with a promotion by $23 \mathrm{wt} \%$.
\end{abstract}

Keywords: vanadium extraction process; vanadium yield; minimum carbon loss; temperature strategy

\section{Introduction}

Vanadium is a widely used rare metal in many areas such as steel-making, aerospace, and chemical industries [1,2]. It is usually found as a by-product in vanadium-titanium magnetite (VTM), and the most popular method of treating vanadium-bearing hot metal is oxygen blow smelting in converter to form vanadium-enriching slag and semi-steel [3]. Residual vanadium in semi-steel must remain low, mostly under $0.05 \mathrm{wt} \%$. Meanwhile, to ensure subsequent steel-making, carbon content in semi-steel needs to above $3.4 \mathrm{wt} \%$ [4]. Therefore, vanadium extraction process demands 'deep devanadium' and 'minimum carbon loss' simultaneously.

The selective oxidation temperature between carbon and vanadium, $T_{\mathrm{sl}}$, a thermodynamic temperature, used to be considered as a key to ensure smelting steps. It related to the transformation from preferential V removal to $C[5,6]$. Most studies tend to the selective oxidation theory, which required the molten bath temperature never went beyond $T_{\text {sl }}$ [4]. However, the demand could not be reached in practice because of the molten bath temperature always exceeded $T_{\mathrm{sl}}$ in middle-late smelting. It ranged from 1340 to $1400{ }^{\circ} \mathrm{C}$ near the end, and was much higher than corresponding $T_{\mathrm{sl}}$. D.X. Huang's study employed the temperature control strategy based on $T_{\mathrm{sl}}$. It showed that carbon loss must be accepted when the molten bath temperature exceeds $T_{\mathrm{sl}}$ for 'deep devanadium', and vanadium removal decreased when the molten bath temperature exceeded $T_{\mathrm{sl}}$ in the middle-late smelting. Thus, previous studies mostly focused on vanadium removal, the reduction of $\left(\mathrm{V}_{2} \mathrm{O}_{3}\right)$ by $\mathrm{C}$ and carbon loss in molten iron was totally ignored [7]. Few studies have concentrated on 'deep devanadium' and 'minimum carbon loss' simultaneously. Further study on a reasonable temperature control strategy is very important to realize these two demands. 
In this paper, Industrial experiments were applied to determine the removal characteristics of $\mathrm{C}$ and $\mathrm{V}$ in various smelting period. Thermodynamic analyses were applied to settle the foundation of new temperature strategy for vanadium extraction. The applicability of new strategy was verified by analyses on final samples and production data.

\section{Experimental Procedure}

Industrial experiments have taken place, and six heats with similar parameters were performed as one to minimize the experimental errors. The original molten iron composition and temperature are listed in Table 1 . The smelting parameters are given in Table 2. The measuring and sampling process is shown in Figure 1.

Table 1. Original compositions and temperatures of molten iron.

\begin{tabular}{cccccc}
\hline \multirow{2}{*}{ Temperature $/{ }^{\circ} \mathbf{C}$} & \multicolumn{5}{c}{ Composition (wt\%) } \\
\cline { 2 - 6 } & $\mathbf{C}$ & $\mathbf{V}$ & $\mathbf{S i}$ & $\mathbf{M n}$ & $\mathbf{T i}$ \\
\hline $1294 \pm 6$ & $4.35 \pm 0.05$ & $0.39 \pm 0.03$ & $0.11 \pm 0.02$ & $0.22 \pm 0.02$ & $0.12 \pm 0.02$ \\
\hline
\end{tabular}

Table 2. Parameters during vanadium extraction smelting.

\begin{tabular}{|c|c|c|c|c|c|c|c|}
\hline $\begin{array}{c}\text { Furnace } \\
\text { Capacity/t }\end{array}$ & $\begin{array}{c}\text { Lance } \\
\text { Height/m }\end{array}$ & $\begin{array}{c}\text { Top Flow Rate } \\
\left(\mathrm{Nm}^{3} / \mathrm{h}\right)\end{array}$ & $\begin{array}{l}\text { Bottom Flow } \\
\text { Rate }\left(\mathrm{Nm}^{3} / \mathrm{h}\right)\end{array}$ & $\begin{array}{c}\text { Number of } \\
\text { Nozzle }\end{array}$ & Ma & $\begin{array}{l}\text { Blowing } \\
\text { Time/s }\end{array}$ & $\begin{array}{c}\text { Coolant } \\
(\mathrm{Kg} / \mathrm{t})\end{array}$ \\
\hline 210 & $1.6 \sim 1.9$ & 24,000 & 1000 & 4 & 1.99 & $\sim 360$ & $41.6 \pm 0.6$ \\
\hline
\end{tabular}

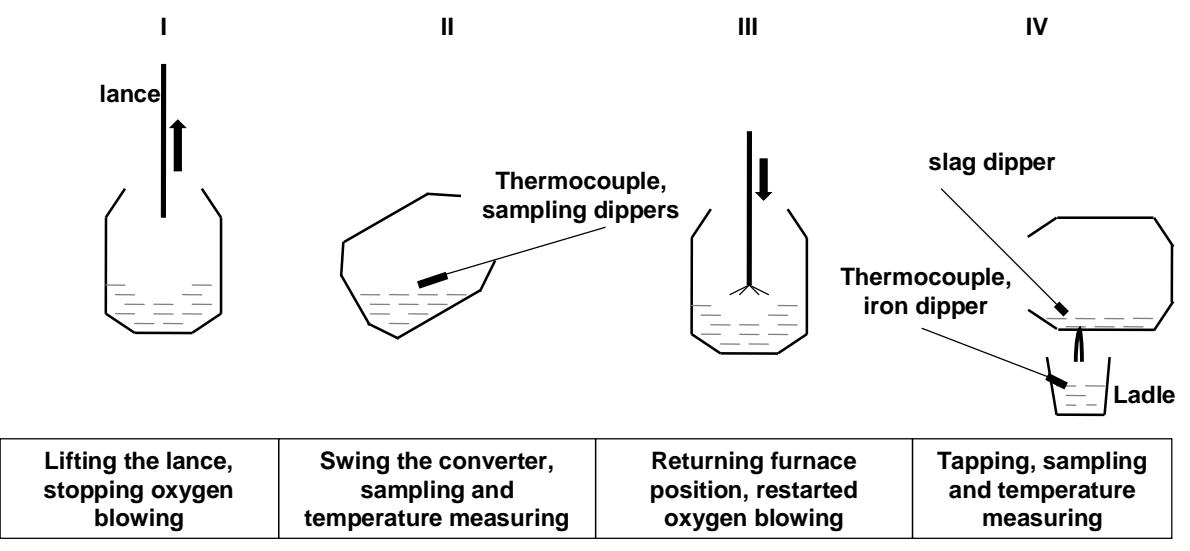

Figure 1. Schematic of sampling and temperature measuring operations.

Coolants were added into molten bath for three times at $60 \mathrm{~s}, 120 \mathrm{~s}$ and $180 \mathrm{~s}$ to ensure the molten bath temperature below $T_{\mathrm{sl}}$ in the earlier smelting [8]. Sampling and temperature measuring were carried out from $210 \mathrm{~s}$ with an interval about $25 \pm 5 \mathrm{~s}$. The total smelting lasted around $360 \mathrm{~s}$ based on production experience. X-Ray Fluorescence analyses (XRF-1800, Rh-target, $60 \mathrm{KV}, 140 \mathrm{~mA}$ ) were applied to determine the compositions of metal and slag.

\section{Results}

The thermodynamic temperature $T_{\mathrm{sl}}$ for each sample was calculated by equaling $\triangle G$ of reaction (1) to reaction (2), as Equation (3).

$$
\begin{gathered}
{[\mathrm{C}]+(\mathrm{FeO})=[\mathrm{Fe}]+\mathrm{CO} \Delta G^{\theta}=98,799-90.76 \mathrm{~T} \mathrm{~J} / \mathrm{mol}} \\
\frac{2}{3}[\mathrm{~V}]+(\mathrm{FeO})=\frac{1}{3}\left(\mathrm{~V}_{2} \mathrm{O}_{3}\right)+[\mathrm{Fe}] \Delta G^{\theta}=-151,376+62.33 T \mathrm{~J} / \mathrm{mol}
\end{gathered}
$$




$$
T_{\mathrm{sl}}=\frac{250,170}{153.09+19.147 \lg \frac{\gamma_{\mathrm{V}_{2} \mathrm{O}_{3}}^{1 / 3} \cdot x_{\mathrm{V}_{2} \mathrm{O}_{3}}^{1 / 3} \cdot(\% \mathrm{C}) \cdot f_{\mathrm{C}}}{(\% \mathrm{OV})^{2 / 3} \cdot f_{\mathrm{V}}^{2 / 3} \cdot P_{\mathrm{CO}}}}
$$

where $x_{\mathrm{V} 2 \mathrm{O} 3}$ was the mole fraction of $\mathrm{V}_{2} \mathrm{O}_{3}$ in slag and $\gamma_{\mathrm{V} 2 \mathrm{O} 3}$ was the activity coefficient. $f_{\mathrm{C}}$ and $f_{\mathrm{V}}$ were the activity coefficients of carbon and vanadium which referred to Equations (4) and (5). ( $\% \mathrm{C})$ and $(\% \mathrm{~V})$ were the mass fractions of carbon and vanadium, respectively. $\mathrm{P}_{\mathrm{CO}}$ was the partial pressure of $\mathrm{CO}$ in the converter.

However, about $55-65 \%\left(\mathrm{~V}_{2} \mathrm{O}_{3}\right)$ in the vanadium slag precipitated by vanadium spinels $\left(\mathrm{FeO} . \mathrm{V}_{2} \mathrm{O}_{3}\right)$ during smelting [9]. Therefore, the current study employed the value from D.X. Huang based on industrial production data, $10^{-5}$ [4].

$$
\begin{aligned}
& \lg f_{\mathrm{C}}=\Sigma e_{\mathrm{C}}^{\mathrm{i}}(\% \mathrm{j})=e_{\mathrm{C}}^{\mathrm{C}}(\% \mathrm{C})+e_{\mathrm{C}}^{\mathrm{V}}(\% \mathrm{~V})+e_{\mathrm{C}}^{\mathrm{Si}}(\% \mathrm{Si})+e_{\mathrm{C}}^{\mathrm{Mn}}(\% \mathrm{Mn})+e_{\mathrm{C}}^{\mathrm{Ti}}(\% \mathrm{Ti})+\ldots \\
& \lg f_{\mathrm{V}}=\Sigma e_{\mathrm{V}}^{\mathrm{j}}(\% \mathrm{j})=e_{\mathrm{V}}^{\mathrm{V}}(\% \mathrm{~V})+e_{\mathrm{V}}^{\mathrm{C}}(\% \mathrm{C})+e_{\mathrm{V}}^{\mathrm{Mn}}(\% \mathrm{Mn})+e_{\mathrm{V}}^{\mathrm{Si}}(\% \mathrm{Si})+e_{\mathrm{V}}^{\mathrm{Ti}}(\% \mathrm{Ti})+\ldots
\end{aligned}
$$

where $e_{\mathrm{C}}^{\mathrm{i}}$ was the interaction coefficient to carbon, and $e_{\mathrm{V}}^{\mathrm{j}}$ was the interaction coefficients to vanadium.

The molten bath temperatures, compositions of metal and slag measured in industrial experiments were listed in Tables 3 and 4. Removal ratios of $\mathrm{C}$ and $\mathrm{V}$ and $T_{\mathrm{sl}}$ for each sample were shown in Table 5.

Table 3. The molten bath temperatures and molten iron compositions (wt $\%$ ) in various time during industrial experiments.

\begin{tabular}{cccccccc}
\hline NO. & Time/s & $\mathbf{C}$ & $\mathbf{V}$ & $\mathbf{S i}$ & $\mathbf{M n}$ & $\mathbf{T i}$ & $\mathbf{T}_{\mathbf{b t}} /\left({ }^{\circ} \mathbf{C}\right)$ \\
\hline 0 & 0 & 4.31 & 0.39 & 0.11 & 0.22 & 0.12 & 1294 \\
$1 \#-1$ & 210 & 4.07 & 0.168 & 0.044 & 0.096 & 0.011 & 1318 \\
$1 \#-2$ & 240 & 4.0 & 0.137 & 0.030 & 0.060 & 0.008 & 1320 \\
$1 \#-3$ & 252 & 3.82 & 0.115 & 0.019 & 0.054 & 0.006 & 1337 \\
$1 \#-4$ & 282 & 3.60 & 0.087 & 0.018 & 0.046 & 0.006 & 1342 \\
$1 \#-5$ & 282 & 3.66 & 0.094 & 0.022 & 0.049 & 0.004 & 1348 \\
$1 \#-6$ & 306 & 3.59 & 0.078 & 0.010 & 0.034 & 0.003 & 1349 \\
$2 \#-1$ * & 366 & 3.54 & 0.051 & 0.006 & 0.026 & 0.001 & 1376 \\
$2 \#-2$ * & 366 & 3.45 & 0.042 & 0.009 & 0.023 & 0.001 & 1382 \\
$2 \#-3$ * & 366 & 3.51 & 0.06 & 0.010 & 0.030 & 0.002 & 1378 \\
$2 \#-4$ * & 372 & 3.61 & 0.053 & 0.007 & 0.027 & 0.001 & 1394 \\
$2 \#-5$ * & 378 & 3.45 & 0.054 & 0.005 & 0.026 & 0.001 & 1382 \\
2\#-6 * & 390 & 3.49 & 0.06 & 0.006 & 0.024 & 0.001 & 1379 \\
\hline
\end{tabular}

* Final samples.

Table 4. Slag compositions (wt $\%$ ) in various time during industrial experiments.

\begin{tabular}{ccccccccc}
\hline NO. & Time/s & $\mathbf{V}_{\mathbf{2}} \mathbf{O}_{\mathbf{3}}$ & $\mathbf{F e O}$ & $\mathbf{S i O}_{\mathbf{2}}$ & $\mathbf{M n O}$ & $\mathbf{T i O}_{\mathbf{2}}$ & $\mathbf{C a O}$ & $\mathbf{M g O}$ \\
\hline 0 & 0 & 1.6 & 90.0 & 2 & 2 & 2 & 1.5 & 1.5 \\
$1 \#-1$ & 210 & 8.2 & 70.6 & 4.4 & 4.4 & 5.8 & 1.6 & 1.4 \\
$1 \#-2$ & 240 & 10.3 & 65.5 & 5.6 & 5.9 & 7.8 & 1.9 & 1.6 \\
$1 \#-3$ & 252 & 10.7 & 62.5 & 5.9 & 6.7 & 8.6 & 1.9 & 1.5 \\
$1 \#-4$ & 282 & 11.1 & 56.5 & 7.2 & 8 & 9.6 & 1.7 & 1.5 \\
$1 \#-5$ & 282 & 11.5 & 54.4 & 8.4 & 8 & 9.2 & 2.0 & 1.7 \\
$1 \#-6$ & 306 & 14.0 & 48.6 & 9.2 & 8.5 & 10.0 & 1.8 & 1.9 \\
$2 \#-1^{*}$ & 366 & 16.2 & 32.4 & 10.2 & 9.8 & 10.5 & 2.0 & 2.0 \\
$2 \#-2$ * & 366 & 17.3 & 34.5 & 10.4 & 10.2 & 11.2 & 2.4 & 1.8 \\
$2 \#-3$ * & 366 & 16.5 & 33.4 & 9.8 & 10.4 & 10.0 & 1.8 & 2.2 \\
$2 \#-4$ * & 372 & 15.7 & 35.4 & 10.2 & 10.2 & 11.4 & 2.0 & 1.8 \\
$2 \#-5$ * & 378 & 16.5 & 30.9 & 10.6 & 11.0 & 10.8 & 2.2 & 2.4 \\
$2 \#-6$ * & 390 & 16.5 & 32.6 & 10.2 & 10.6 & 10.6 & 2.4 & 2.0 \\
\hline
\end{tabular}

\footnotetext{
* Final samples.
} 
Table 5. Removal ratios, $T_{\mathrm{sl}}$ and $T_{\mathrm{eq}}$ in various time during industrial experiments.

\begin{tabular}{|c|c|c|c|c|c|c|c|c|}
\hline NO. & Time/s & V & $\begin{array}{l}\text { V Removal } \\
\text { Ratio/wt } \%\end{array}$ & $\mathrm{C}$ & $\begin{array}{l}\text { C Removal } \\
\text { Ratio/wt } \%\end{array}$ & $T_{\mathrm{bt}} /\left({ }^{\circ} \mathrm{C}\right)$ & $T_{\mathrm{sl}} /\left({ }^{\circ} \mathrm{C}\right)$ & $T_{\text {eq }} /\left({ }^{\circ} \mathrm{C}\right)$ \\
\hline 0 & 0 & 0.39 & - & 4.31 & 0.0 & 1294 & 1382 & 1782 \\
\hline $1 \#-1$ & 210 & 0.168 & 56.9 & 4.07 & 5.6 & 1318 & 1295 & 1595 \\
\hline $1 \#-2$ & 240 & 0.137 & 64.9 & 4.0 & 7.2 & 1320 & 1285 & 1566 \\
\hline $1 \#-3$ & 252 & 0.115 & 70.5 & 3.82 & 11.4 & 1337 & 1292 & 1568 \\
\hline $1 \#-4$ & 282 & 0.087 & 77.7 & 3.60 & 16.5 & 1342 & 1294 & 1547 \\
\hline $1 \#-5$ & 282 & 0.094 & 75.9 & 3.66 & 15.1 & 1348 & 1294 & 1542 \\
\hline $1 \#-6$ & 306 & 0.078 & 80.0 & 3.59 & 16.7 & 1349 & 1281 & 1504 \\
\hline $2 \#-1$ * & 366 & 0.051 & 86.9 & 3.54 & 17.9 & 1376 & 1260 & 1407 \\
\hline $2 \#-2$ * & 366 & 0.042 & 89.2 & 3.45 & 20.0 & 1382 & 1257 & 1402 \\
\hline $2 \#-3$ * & 366 & 0.06 & 84.6 & 3.51 & 18.6 & 1378 & 1272 & 1408 \\
\hline $2 \#-4$ * & 372 & 0.053 & 86.4 & 3.61 & 16.2 & 1394 & 1257 & 1415 \\
\hline $2 \#-5$ * & 378 & 0.054 & 86.2 & 3.45 & 20.0 & 1382 & 1271 & 1389 \\
\hline $2 \#-6$ * & 390 & 0.06 & 84.6 & 3.49 & 19.0 & 1379 & 1273 & 1412 \\
\hline
\end{tabular}

* Final samples.

\section{Discussions}

\section{1. $V$ andC Removal in Various Temperatures}

Variations on molten bath temperatures, $T_{\mathrm{sl}}, \mathrm{V}, \mathrm{C}$ and $\mathrm{V}_{2} \mathrm{O}_{3}$ contents, were shown in Figure 2. The molten bath temperature increased due to the oxidation of dissolved elements. It turned out more rapidly without coolant addition in the middle-late smelting. $T_{\mathrm{sl}}$ decreased during vanadium extraction with the decrease in $\mathrm{V}$ content and increase in $\left(\mathrm{V}_{2} \mathrm{O}_{3}\right)$ in slag, as shown in Figure $2 \mathrm{~b}$. The molten bath temperature was controlled below $T_{\mathrm{sl}}$ in the earlier smelting and became higher than $T_{\mathrm{sl}} 23^{\circ} \mathrm{C}$ at $210 \mathrm{~s}$.

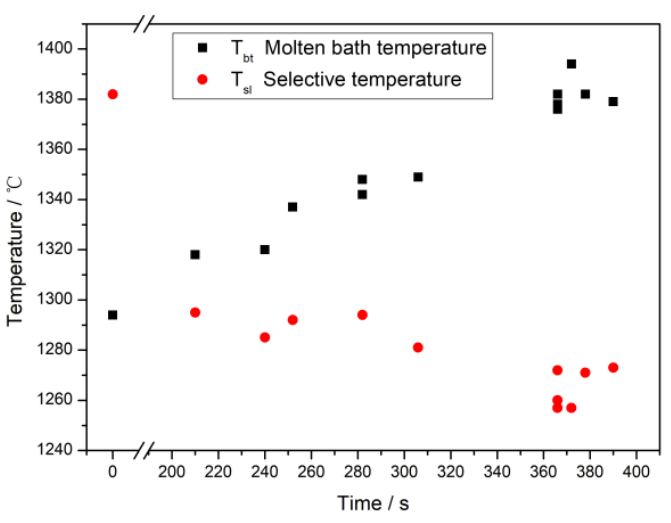

(a)

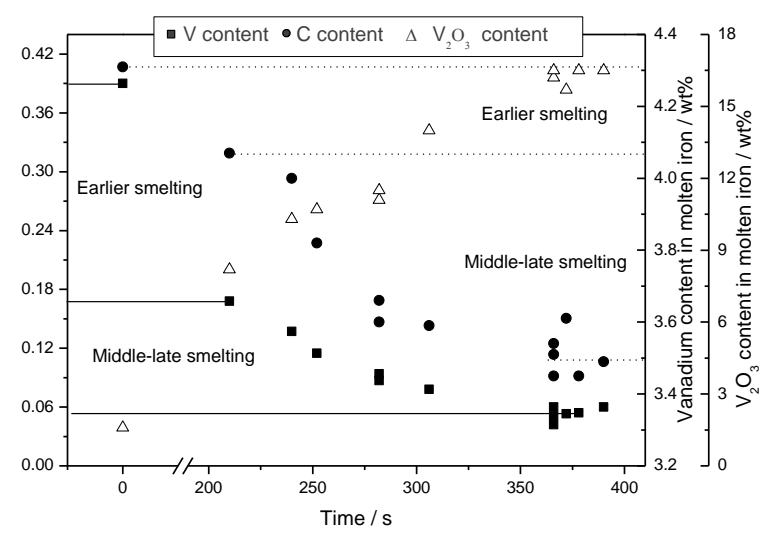

(b)

Figure 2. Variations on $\mathrm{V}, \mathrm{C},\left(\mathrm{V}_{2} \mathrm{O}_{3}\right)$, the molten bath temperature and $T_{\mathrm{sl}}$. (a) variation on $T_{\mathrm{bt}}$ and $T_{\mathrm{sl}},(\mathbf{b})$ variation on $\mathrm{V}$, C, and $\left(\mathrm{V}_{2} \mathrm{O}_{3}\right)$.

The removal ratio of $\mathrm{V}$ and $\mathrm{C}$ at $210 \mathrm{~s}$ were $56.9 \mathrm{wt} \%$ and $5.6 \mathrm{wt} \%$. The removal ratios of the final point were $86.3 \mathrm{wt} \%$ and $19 \mathrm{wt} \%$ (average), as shown in Table 5 . As the molten bath temperature exceeded $T_{\mathrm{sl}}$ in the middle-late smelting (after $210 \mathrm{~s}$ ), vanadium oxidation has lost thermodynamic advantage to carbon. Vanadium removal showed a weak tendency compared with the earlier smelting. Therefore, only about $30 \mathrm{wt} \% \mathrm{~V}$ was removed in middle-late smelting. However, carbon removal showed an opposite feature and has no longer been suppressed by vanadium removal. Therefore, about $13.4 \mathrm{wt} \% \mathrm{C}$ was removed in middle-late smelting, and it was 2.4 times more than the earlier smelting (5.6 wt $\%)$, as shown in Table 5. Thus it can be seen, vanadium removal efficiency decreased when the molten bath temperature exceeded $T_{\mathrm{sl}}$ in the middle-late smelting. However, carbon 
removal seemed to climb up rapidly. It was certain to desire a reasonable principle for final temperature control to assure 'enhance vanadium removal' with 'minimum carbon loss'.

\subsection{Thermodynamic Analyses of Vanadium Extraction}

The present study considered that carbon and vanadium oxidation in the molten bath were mainly indirect [10]. Oxygen was transferred by ferrous oxide (FeO). Carbon monoxide $(\mathrm{CO})$ was considered as the oxidative product of $\mathrm{C}$ as it was saturated in molten iron $(\geq 3.4 \mathrm{wt} \%)$. In addition, vanadium trioxide $\left(\mathrm{V}_{2} \mathrm{O}_{3}\right)$ would be reduced by $\mathrm{C}$, as displayed in Equation (6). The standard Gibbs free energies $\left(\Delta G^{\theta}\right)$ of reaction (1), (2) and (6) with various temperatures were showed as follows Figure 3.

$$
\frac{1}{3}\left(\mathrm{~V}_{2} \mathrm{O}_{3}\right)+[\mathrm{C}]=\frac{2}{3}[\mathrm{~V}]+\mathrm{CO} \Delta G^{\theta}=250,170-153.09 \mathrm{~T} \mathrm{~J} / \mathrm{mol}
$$

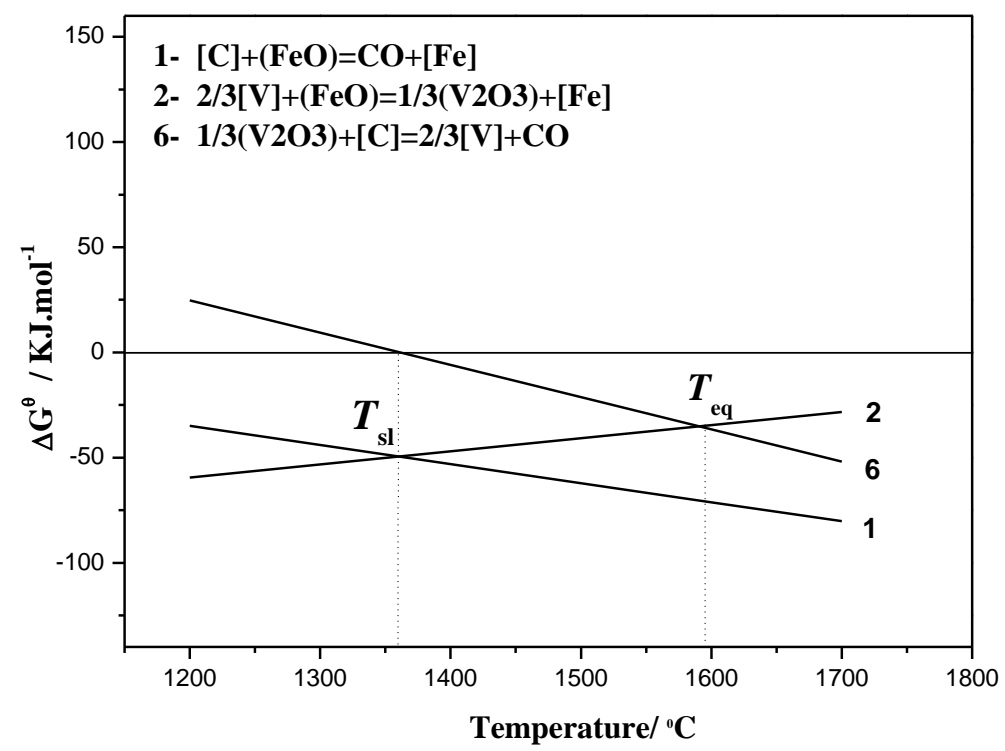

Figure 3. Relationship between $\Delta G^{\theta}$ and temperature.

The molten bath temperature exceeded $T_{\mathrm{sl}}$ rapidly without coolant addition in the middle-late smelting, as shown in Figure 2a. The removal of $\mathrm{C}$ is prior to $\mathrm{V}$ in this period, and $\left(\mathrm{V}_{2} \mathrm{O}_{3}\right)$ in the slag also was reduced by $\mathrm{C}$, as shown in Figure 3. However, $\triangle G$ of reaction (2) was still less than (6), which meant the thermodynamic driving force of vanadium removal was greater than the reduction. $\mathrm{V}$ removal and reduction of $\left(\mathrm{V}_{2} \mathrm{O}_{3}\right)$ exist simultaneously.

As the molten bath temperature increasing continuously, there was a temperaturemade $\Delta G$ of reaction (2) equal to (6). It stood for the thermodynamic equilibrium of vanadium removal and reduction, as shown in Figure 3 [11,12]. In this study, this temperature was described as 'The equilibrium temperature of vanadium oxidation and reduction, $T_{\text {eq' }}$. A coupled reaction represented $V$ removal was deduced by equalizing $\Delta \mathrm{G}$ of reaction (2) and (6), as displayed in Equation (7). $T_{\text {eq }}$ was calculated by the following Equation (8). $T_{\text {eq }}$ for each sample was listed in Table 5 , and variation on the molten bath temperature and $T_{\text {eq }}$ was shown in Figure 4.

$$
\begin{gathered}
\frac{4}{3}[\mathrm{~V}]+(\mathrm{FeO})+\mathrm{CO}=\frac{2}{3}\left(\mathrm{~V}_{2} \mathrm{O}_{3}\right)+[\mathrm{Fe}]+[\mathrm{C}] \Delta G^{\theta}=-401,551+215.42 T \mathrm{~J} / \mathrm{mol} \\
T_{\mathrm{eq}}=\frac{401,551}{215.42+19.147 \lg \frac{\gamma_{\mathrm{V}_{2} \mathrm{O}_{3}}^{2 / 3} \cdot x_{\mathrm{V}_{2} \mathrm{O}_{3}}^{2 / 3} \cdot[\% \mathrm{C}] \cdot f_{\mathrm{C}}}{\left[\% \mathrm{~V}^{4 / 3} \cdot f_{\mathrm{V}}^{4 / 3} \cdot a_{\mathrm{FeO}} \cdot P_{\mathrm{CO}}\right.}}
\end{gathered}
$$




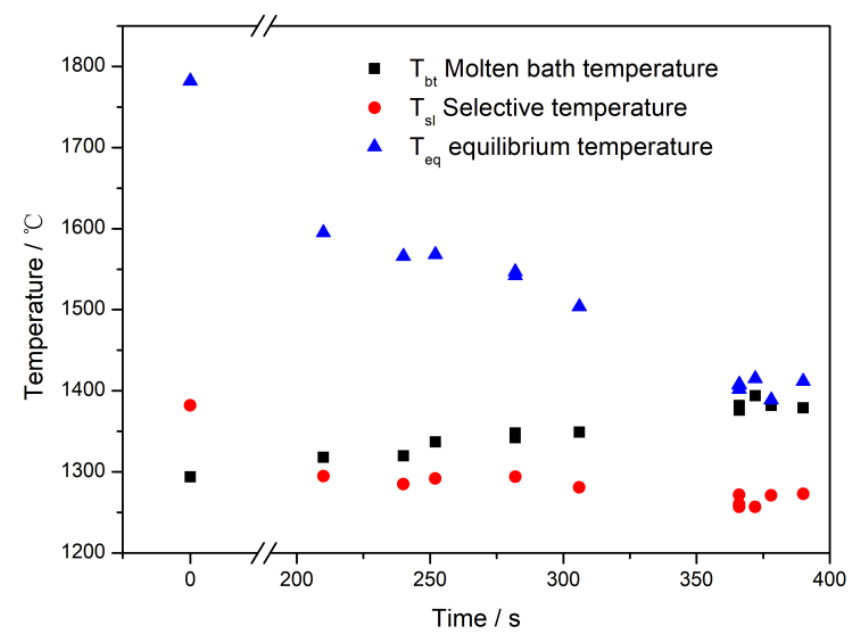

Figure 4. Variations on the molten bath temperature and $T_{\text {eq. }}$.

Thus, a new temperature strategy for 'enhance vanadium yield' with 'minimum carbon loss' can be proposed. In the earlier smelting, the molten bath temperature must be controlled below $T_{\mathrm{sl}}$ by coolant addition. In middle-late smelting, the molten bath temperature exceeding $T_{\mathrm{sl}}, T_{\text {eq }}$ was considered as the high-limit temperature. Potential for vanadium removal could be fully exploited and excessive carbon loss was avoided.

\subsection{Applicability Analyses of $T_{\text {eq }}$ for the Final Temperature}

\subsubsection{Final Samples}

The theoretical residual vanadium in molten iron at the final point was calculated based on Equations (9) and (10) which deduced from Equations (3) and (8), respectively. Six final samples were treated as repetitive measurements in one heat. The Mean Absolute Difference (MAD) between theoretical vanadium contents and measurements were applied to evaluate the applicability of $T_{\mathrm{sl}}$ and $T_{\mathrm{eq}}$ on temperature strategy, as shown in Figure 5.

$$
\begin{gathered}
(\% \mathrm{~V})_{\mathrm{sl}}=\left[\frac{\gamma_{\mathrm{V}_{2} \mathrm{O}_{3}}^{1 / 3} \cdot x_{\mathrm{V}_{2} \mathrm{O}_{3}}^{1 / 3} \cdot(\% \mathrm{C}) \cdot f_{\mathrm{C}}}{10^{(250,170 / T-153 \cdot 09) / 19 \cdot 147} \cdot f_{\mathrm{V}}^{2 / 3} \cdot P_{\mathrm{CO}}}\right]^{\frac{3}{2}} \\
(\% V)_{\mathrm{eq}}=\left[\frac{\gamma_{\mathrm{V}_{2} \mathrm{O}_{3}}^{2 / 3} \cdot x_{\mathrm{V}_{2} \mathrm{O}_{3}}^{2 / 3} \cdot(\% \mathrm{C}) \cdot f_{\mathrm{C}}}{10^{(401,551 / T-219 \cdot 422) / 19 \cdot 147} \cdot f_{\mathrm{V}}^{4 / 3} \cdot a_{\mathrm{FeO}} \cdot P_{\mathrm{CO}}}\right]^{\frac{3}{4}}
\end{gathered}
$$

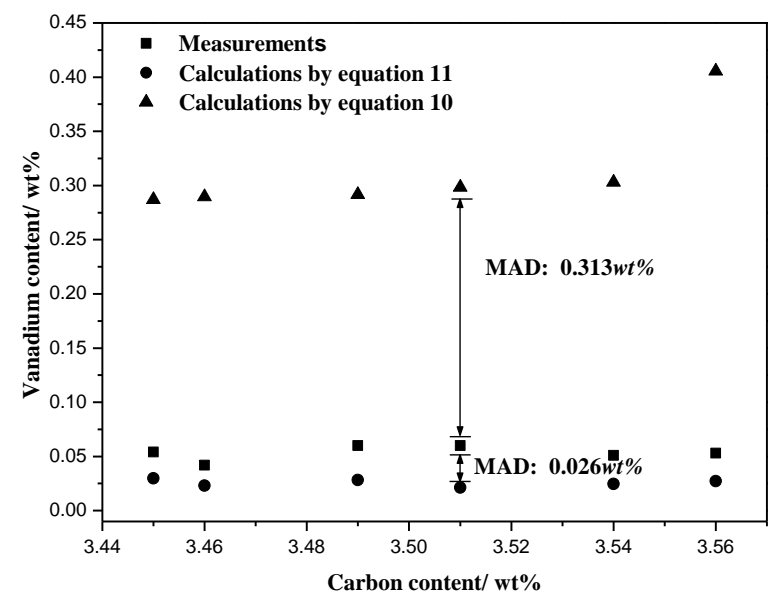

Figure 5. Theoretical vanadium contents and measuring values at the final. 
Theoretical vanadium contents was a bit lower than measurements because of the idealized status. The MAD between measurements and theoretical vanadium content calculated based on $T_{\mathrm{sl}}$ (Equation (10)) was $0.313 \mathrm{wt} \%$ (average). The theoretical values were much higher than measurements, which meant mistakes in calculation foundation. The MAD based on $T_{\text {eq }}$ (Equation (10)) was $0.026 \mathrm{wt} \%$ (average) and theoretical values were a little lower than measurements. It showed a better fitting with measurements. Thus, it can be seen, $T_{\text {eq }}$ should be considered as the thermodynamic basis for describing behaviors in middle-late smelting of vanadium extraction rather than $T_{\mathrm{sl}}$.

\subsubsection{Production Data}

The temperature strategy was applied in Pansteel. The residual vanadium, molten bath temperature and $T_{\text {eq }}$ at the final were also discussed based on production data. The residual vanadium, the temperature differences $\left(\Delta T\right.$, between $T_{\text {eq }}$ and the molten bath temperature) in the final point were shown in Figure 6.

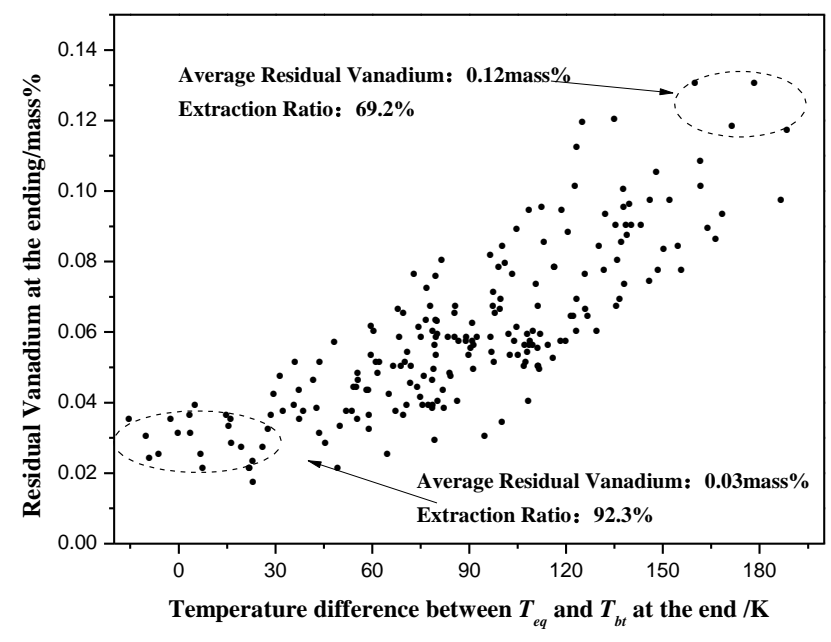

Figure 6. Relationship between the residual vanadium and $\Delta T$ at the final.

The temperature differences in most heats were far above zero, which showed the poor understanding on temperature control. The residual vanadium decreased with the decrease in $\Delta T$. It did not decrease further when $\Delta T$ approached zero, as shown in Figure 6. The thermodynamic driving force of vanadium removal was bigger than reduction when $\Delta T>0$, there was still potential on vanadium removal. Therefore, residual vanadium contents decreased with the decrease in $\Delta T$. Vanadium removal and reduction showed fluctuant equilibrium status when the molten pool temperature exceeded $T_{\text {eq }}$ (i.e., $\Delta T<0$ ).

With the decrease in $\Delta T$, the potential for vanadium removal in middle-late smelting has been fully developed. The vanadium removal ratio has increased from $69.2 \mathrm{wt} \%$ to $92.3 \mathrm{wt} \%$ with a promotion by $23 \mathrm{wt} \%$. However, the serious carbon loss must be avoided when the molten bath temperature exceeded $T_{\text {eq. }} T_{\text {eq }}$ must be considered as a maximum temperature limit of the final stage in vanadium extraction.

\section{Conclusions}

(1) A temperature strategy of vanadium extraction process has been developed to consider the effects of $T_{\mathrm{sl}}$ in the earlier smelting and $T_{\text {eq }}$ for the high-limit temperature to ensure 'enhance vanadium removal' with 'minimum carbon loss'.

(2) The vanadium removal rate was highly efficient accompanied by slight carbon removal when the molten bath temperature was lower than $T_{\mathrm{sl}}$. The removal rate of vanadium decreased and carbon removal increased when the molten bath temperature exceeded $T_{\mathrm{sl}}$. 
(3) Vanadium removal efficiency remained poor while significant carbon loss was expected when the melt temperature went over $T_{\text {eq }}$, and $T_{\text {eq }}$ must be considered as the high-limit temperature in vanadium extraction.

(4) With the optimized temperature strategy, vanadium removal increased from $69.2 \mathrm{wt} \%$ to $92.3 \mathrm{wt} \%$ with a promotion by $23 \mathrm{wt} \%$ by production data.

Author Contributions: Conceptualization, Z.-Y.Z. and P.T.; methodology, Z.-Y.Z. and P.T.; validation, Z.-Y.Z.; formal analysis, Z.-Y.Z. and P.T.; investigation, Z.-Y.Z. and P.T.; resources, P.T.; data curation, Z.-Y.Z.; writing—original draft preparation, Z.-Y.Z.; writing—review and editing, Z.-Y.Z. and P.T.; visualization, Z.-Y.Z.; supervision, P.T. All authors have read and agreed to the published version of the manuscript.

Funding: This research received no external funding.

Institutional Review Board Statement: Not applicable.

Informed Consent Statement: Not applicable.

Data Availability Statement: Data are contained within the article.

Conflicts of Interest: The authors declare no conflict of interest.

\section{References}

1. Edward, J.; Maxim, I.; Kenneth, M. Reduction of Vanadium(V) by Iron(II)-Bearing Minerals. Minerals 2021, 11, 316. [CrossRef]

2. Lidiane, M.A.; Heide, M.; Gaebler, D.J.; Silva, W.E.; Belian, M.F.; Lira, E.C.; Crans, D.C. Acute Toxicity Evaluation of Non-Innocent Oxidovanadium(V) Schiff Base Complex. Inorganics 2021, 9, 42. [CrossRef]

3. Zhang, J.H.; Zhang, W.; Xue, Z.L. An Environment-Friendly Process Featuring Calcified Roasting and Precipitation Purification to Prepare Vanadium Pentoxide from the Converter Vanadium Slag. Metals 2019, 9, 21. [CrossRef]

4. Huang, D.X. Vanadium Extracting and Steelmaking; Metallurgical Industry Press: Beijing, China, 2010; pp. 52-53.

5. Hong, Y.; Peng, J.; Sun, Z.; Yu, Z.; Wang, A.; Wang, Y.; Liu, Y.-Y.; Xu, F.; Sun, L.-X. Transition Metal Oxodiperoxo Complex Modified Metal-Organic Frameworks as Catalysts for the Selective Oxidation of Cyclohexane. Materials 2020, 13, 829. [CrossRef] [PubMed]

6. Condruz, M.R.; Matache, G.; Paraschiv, A.; Badea, T.; Badilita, V. High Temperature Oxidation Behavior of Selective Laser Melting Manufactured IN 625. Metals 2020, 10, 668. [CrossRef]

7. Xiang, J.Y.; Xin, W.A.N.G.; Pei, G.S.; Huang, Q.Y.; Lü, X.W. Recovery of vanadium from vanadium slag by composite roasting with $\mathrm{CaO} / \mathrm{MgO}$ and leaching. Trans. Nonferrous Metals Soc. China 2020, 30, 3114. [CrossRef]

8. Penz, F.M.; Schenk, J.; Ammer, R.; Klösch, G.; Pastucha, K.; Reischl, M. Diffusive Steel Scrap Melting in Carbon-Saturated Hot Metal-Phenomenological Investigation at the Solid-Liquid Interface. Materials 2019, 12, 1358. [CrossRef] [PubMed]

9. Zhang, S.-Q.; Xie, B.; Wang, Y.; Guan, T.; Cao, H.L.; Zeng, X.L. Reaction of $\mathrm{FeOV}_{2} \mathrm{O}_{5}$ System at High Temperature. J. Iron Steel Res. Int. 2012, 19, 33. [CrossRef]

10. Chen, S.K.; Cai, Z.J. An Improved Dynamic Model of the Vanadium Extraction Process in Steelmaking Converters. Appl. Sci. 2020, 10, 111. [CrossRef]

11. Zhou, C.G.; Li, J.; Wu, H. Dependence of Temperature and Slag Composition on Dephosphorization at the First Deslagging in BOF Steelmaking Process. High Temp. Mater. Process. 2014, 49, 24. [CrossRef]

12. Wang, X.H.; Wang, H.J. Converter practice in China with respect to steelmaking and ferroalloys. Miner. Process. Extr. Metall. 2019, 128, 46. [CrossRef] 